\title{
The Karaman score: A new diagnostic score for acute appendicitis
}

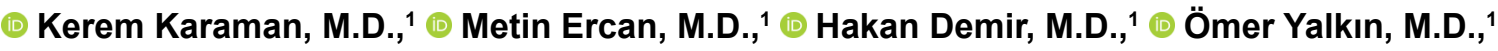 \\ Yener Uzunoğlu, M.D., ${ }^{1}$ - Kemal Gündoğdu, M.D., ${ }^{1}$ () İsmail Zengin, M.D., ${ }^{1}$ \\ (1) Yakup Ersel Aksoy, M.D., ${ }^{2}$ 다 Erdal Birol Bostancı, M.D. ${ }^{1}$
}

\begin{abstract}
${ }^{1}$ Department of General Surgery, Sakarya University Training and Research Hospital, Sakarya-Turkey
\end{abstract}
${ }^{2}$ Department of Radiology, Sakarya University Training and Research Hospital, Sakarya-Turkey

\begin{abstract}
BACKGROUND: The Karaman score is a novel diagnostic scoring system consisting of 6 parameters. The aim of the present study was to assess the diagnostic performance of the Karaman score in comparison with the Alvarado score.

METHODS: A total of 200 patients who underwent an appendectomy were enrolled in the study (research registry number: 2290).

RESULTS: The cutoff threshold of the Karaman score in distinguishing acute appendicitis from negative appendectomy was $\geq 9$ with $84.3 \%$ sensitivity, $64.7 \%$ specificity, $92.1 \%$ positive predictive value (PPV), and $45.8 \%$ negative predictive value (NPV). The cutoff threshold of the Alvarado score in distinguishing acute appendicitis from negative appendectomy was $\geq 8$ with $72.9 \%$ sensitivity, $70.6 \%$ specificity, 92.4\% PPV, and 34.8\% NPV. In multivariate logistic regression analysis, an Alvarado $\geq 8$ score (Odds ratio [OR]:6.644, 95\% confidence interval [Cl]: 2.854-15.466; $\mathrm{p}<0.00 \mathrm{I}$ ) and a Karaman $\geq 9$ score (OR: $10.374,95 \%$ Cl: 4.383-24.558; $\mathrm{p}<0.00 \mathrm{I})$ were each individually predictive in distinguishing acute appendicitis from negative appendectomy when correction was made according to age and gender. However, when both scores were evaluated together, the Alvarado score $\geq 8$ lost its efficacy (OR:I.838, 95\% Cl: 0.5। 7-6.530; $\mathrm{p}=0.347$ ), whereas the Karaman score $\geq 9$ retained its predictive power (OR:6.586, 95\% Cl: I.893-22.9। 7; $\mathrm{p}=0.003$ ).
\end{abstract}

CONCLUSION: The Karaman score was more predictive than the Alvarado score in distinguishing acute appendicitis from a negative appendectomy.

Keywords: Acute appendicitis; Alvarado score; Karaman score; negative appendectomy; sensitivity; specificity.

\section{INTRODUCTION}

Acute appendicitis is the most common abdominal emergency requiring surgery, and has an estimated life time prevalence of $7 \% .^{[I]}$ Despite the development of new technologies in radio-diagnostics and the availability of many laboratory tests and scoring systems, diagnosis of appendicitis remains challenging. ${ }^{[2-4]}$ The Alvarado score is the most well-known and best performing scoring system in validation studies. ${ }^{[5]}$ The Karaman score is a novel diagnostic tool consisting of 6 parameters based on the patient's symptoms and signs supported by laboratory tests, and is easy to perform.
The primary outcome of the present study was to determine the diagnostic performance of the Karaman score in acute appendicitis. The second outcome was to compare the results of the Karaman score with the Alvarado score. Finally, the third outcome was to determine the diagnostic compliance of the Karaman and Alvarado scores with ultrasound (US) and computerized tomography (CT) findings.

\section{MATERIALS AND METHODS}

After receiving ethics committee approval, the study was conducted between May 2014 and December 2015 in the

Cite this article as: Karaman K, Ercan M, Demir H, Yalkın Ö, Uzunoğlu Y, Gündoğdu K, et al. The Karaman score: A new diagnostic score for acute appendicitis. Ulus Travma Acil Cerrahi Derg 2018;24:545-551.

Address for correspondence: Kerem Karaman, M.D.

Köprübaşı Mah, Huzur Liva 3 Sitesi, No: 31, B Blok, Daire: 6, Serdivan, 54100 Adapazarı, Turkey

Tel: +90 264 - 8884000 / 2209 E-mail: karaman_kerem@yahoo.com.tr 
general surgery department of Sakarya University Training and Research Hospital. Informed consent was obtained from all of the patients. Patients were included if they were $\geq 18$ years of age. A total of 200 patients qualified for the study during the research period. All of the patients were scored using the Alvarado and Karaman scoring systems. The Alvarado score includes 8 parameters, whereas the Karama score uses 6 parameters.

\section{The Karaman Scoring System}

The Karaman scoring system consists of 6 parameters. Of these, 2 symptomatic parameters are anorexia and migratory right iliac fossa pain. Rebound tenderness in the right iliac fossa and aggravation of peritoneal irritation in the right iliac fossa with heavy coughing are the 2 positive signs. Additionally, a leukocyte count of $>10.000 / \mathrm{mm}^{3}$ and a left shift of neutrophils of $>70 \%$ are the positive laboratory parameters. Each positive parameter in the Karaman score generates 2 points, while I point is removed for each negative parameter. The maximum number of points for diagnosis is 12 and the minimum is -6 points.

\section{Study Design}

A scoring chart with both the Karaman and the Alvarado score criteria was completed by the attending surgeon at the time of presentation prior to radiological examinations (US, CT) (Table I). The appendectomy decision was based solely on the surgeon's clinical judgment after taking into consideration all of the clinical, laboratory, and radiological findings. The Karaman and Alvarado scores were used only for research purposes.

Patients were monitored following admission, surgery, and through discharge from the hospital. Daily follow-up included monitoring of vitals 3 times a day and systemic examination once a day. Postoperative histopathology findings were collected and correlated with the scoring systems. The study was terminated after 200 consecutive appendectomies.

The diagnostic performance of the Karaman and Alvarado scores was determined according to sensitivity, specificity, and the positive predictive value (PPV) and negative predictive value (NPV). The diagnostic compliance of the Karaman and Alvarado scores with US and CT findings was also analyzed.

\section{Statistical Analysis}

Data analysis was performed using SPSS Statistics for Windows, Version 17.0 (SPSS, Inc., Chicago, IL, USA). Normal distribution of continuous variables was determined using the Kolmogorov-Smirnov test. Continuous variables were represented by the median (minimum-maximum), otherwise, the number of cases and percentages were used for categorical data. The Mann-Whitney $U$ test was applied for comparisons of the non-normally distributed data. Categorical variables were analyzed using a chi-square or the McNemar test, as appropriate. The diagnostic performance of the Alvarado and
Table I. The Karaman and Alvarado scoring systems

\begin{tabular}{|c|c|c|}
\hline Karaman score & Positive (+) & Negative (-) \\
\hline \multicolumn{3}{|l|}{ Symptoms } \\
\hline Anorexia & +2 & -1 \\
\hline Migratory right iliac fossa pain & +2 & \\
\hline \multicolumn{3}{|l|}{ Signs } \\
\hline \multicolumn{3}{|l|}{ Rebound tenderness in right } \\
\hline iliac fossa & +2 & -1 \\
\hline \multicolumn{3}{|l|}{ Peritoneal irritation in right iliac } \\
\hline fossa with heavy coughing & +2 & -1 \\
\hline \multicolumn{3}{|l|}{ Laboratory findings } \\
\hline $\mathrm{WBC}>10.000 / \mathrm{mm}^{3}$ & +2 & -1 \\
\hline $\mathrm{PMNL}>70 \%$ & +2 & -1 \\
\hline Total points & 12 & -6 \\
\hline \multicolumn{3}{|l|}{ Alvarado score } \\
\hline \multicolumn{3}{|l|}{ Symptoms } \\
\hline Anorexia & +1 & \\
\hline Migratory right iliac fossa pain & +1 & \\
\hline Nausea/vomiting & +1 & \\
\hline \multicolumn{3}{|l|}{ Signs } \\
\hline Tenderness in right iliac fossa & +2 & \\
\hline \multicolumn{3}{|l|}{ Rebound tenderness in right } \\
\hline iliac fossa & +1 & \\
\hline \multicolumn{3}{|l|}{ Elevation of body temperature } \\
\hline$\left(\geq 37.3 C^{\circ}\right)$ & +1 & \\
\hline \multicolumn{3}{|l|}{ Laboratory findings } \\
\hline$W B C>10.000 / \mathrm{mm}^{3}$ & +1 & \\
\hline PMNL >75\%) & +1 & \\
\hline Total points & 10 & 0 \\
\hline
\end{tabular}

PMNL: Polymorphonuclear leukocytes; WBC: White blood cell.

the Karaman scoring systems was evaluated using receiver operating characteristic (ROC) curve analysis. The optimal cutoff point of each scoring system was assumed to provide the maximum sum of sensitivity and specificity. The diagnostic performance of the scoring systems was evaluated, including sensitivity, specificity, PPV, and NPV. The agreement between the Alvarado and Karaman scores was evaluated by calculating the kappa coefficient. Analysis of the best scoring system for diagnosis was determined using multiple logistic regression analysis after adjustment for age and gender. An adjusted odds ratio (OR) and $95 \%$ confidence interval $(\mathrm{Cl})$ for each independent variable was also calculated. A $P$ value less than 0.05 was considered statistically significant.

\section{RESULTS}

A total of 200 patients underwent appendectomy and were included in the study. Of these, I 8 patients were male (59\%) 
Table 2. Patient demographic data and characteristics

\begin{tabular}{|c|c|}
\hline Variables & $\mathbf{n}=\mathbf{2 0 0}$ \\
\hline Age (years), median (min-max) & $32(18-78)$ \\
\hline \multicolumn{2}{|l|}{ Gender, n (\%) } \\
\hline Male & I I8 (59) \\
\hline Female & $82(4 I)$ \\
\hline \multicolumn{2}{|l|}{ Histopathological signs, n (\%) } \\
\hline Appendicitis & $166(83)$ \\
\hline Acute appendicitis & $136(68)$ \\
\hline Perforated appendicitis & $18(9)$ \\
\hline Phlegmonous appendicitis & $12(6)$ \\
\hline Non-appendicitis & $34(17)$ \\
\hline Lymphoid hyperplasia & $20(10)$ \\
\hline Normal appendix & $12(6)$ \\
\hline Meckel's diverticulitis & $\mathrm{I}(0.5)$ \\
\hline Over cyst rupture & $\mathrm{I}(0.5)$ \\
\hline \multicolumn{2}{|l|}{ Localization, n (\%) } \\
\hline Retrocecal & $146(73)$ \\
\hline Subcecal & $37(18.5)$ \\
\hline Peri-ileal & $9(4.5)$ \\
\hline Pelvic & $4(2)$ \\
\hline Retroileal & $4(2)$ \\
\hline Alvarado score, median (min-max) & $8(2-10)$ \\
\hline Karaman score, median (min-max) & $9(-3-12)$ \\
\hline
\end{tabular}

and 82 patients were female (4I\%). The median age was 32 years (min-max: 18-72 years). In all, 166 patients (83\%) had histopathologically confirmed acute appendicitis. Of these, 18 patients $(9 \%)$ had perforated acute appendicitis, whereas 12 patients $(6 \%)$ had phlegmonous appendicitis. Thirty-four patients $(17 \%)$ had a negative appendectomy. In that group, 20 patients (10\%) had lymphoid hyperplasia, 12 patients $(6 \%)$ had a normal appendix, I patient $(0.5 \%)$ had Meckel's diverticulitis, and I patient $(0.5 \%)$ had over cyst rupture. The most frequently observed localization of the appendix was retrocecal ( 146 patient, $73 \%$ ) followed by subcecal (37 patients, 18.5\%), peri-ilieal ( 9 patients, $4.5 \%$ ), pelvic (4 patients, $2 \%$ ), and retroileal (4 patients, $2 \%$ ), respectively. The median Alvarado score among the patients was 8 (min-max: 2-10), whereas the median Karaman score was 9 (min-max: -3-12) (Table 2).

No significant difference was found according to median age between the patients with acute appendicitis and those with a negative appendectomy $(p=0.102)$. However, the male /female ratio was significantly higher in patients with acute appendicitis and the negative appendectomy rate was significantly higher in females $(p=0.02)$. US could not significantly differentiate acute appendicitis from negative appendectomy $(p=0.06 \mathrm{I})$. On the other hand, the detection of acute appendicitis by $\mathrm{CT}$ was
Table 3. Comparison of patient characteristics and demographic data according to acute appendicitis and negative appendectomy results

\begin{tabular}{|c|c|c|c|}
\hline Acute appendicitis & $\begin{array}{c}\text { Negative } \\
(n=34)\end{array}$ & $\begin{array}{l}\text { Positive } \\
(n=166)\end{array}$ & $\mathbf{p}$ \\
\hline \multicolumn{4}{|l|}{ Age (years), } \\
\hline median (min-max) & $29(18-46)$ & $32(18-78)$ & $0.102^{\dagger}$ \\
\hline Gender, n (\%) & & & $0.020^{\ddagger}$ \\
\hline Male & I4 (4I.2) & $104(62.7)$ & \\
\hline Female & $20(58.8)$ & $62(37.3)$ & \\
\hline US findings, $n(\%)$ & & & $0.06 I^{\ddagger}$ \\
\hline No & $10(58.8)$ & $18(33.3)$ & \\
\hline Yes & $7(4 \mid .2)$ & $36(66.7)$ & \\
\hline CT findings, $n(\%)$ & & & $<0.00 I^{\ddagger}$ \\
\hline No & 14 (5।.9) & $13(9.0)$ & \\
\hline Yes & $13(48.1)$ & 132 (91.0) & \\
\hline $\begin{array}{l}\text { Alvarado score, } \\
\text { median (min-max) }\end{array}$ & $6.5(2-10)$ & $8(3-10)$ & $<0.00 \mathrm{I}^{\dagger}$ \\
\hline $\begin{array}{l}\text { Karaman score, } \\
\text { median (min-max) }\end{array}$ & $3(-3-12)$ & $10.5(-3-12)$ & $<0.00 \mathrm{It}^{\dagger}$ \\
\hline
\end{tabular}

†Mann-Whitney $U$ test; PPearson's chi square test.

CT: Computerized tomography; US: Ultrasound (abdominal).

significantly higher $(p=0.00 \mathrm{I})$. The median Alvarado score in patients with acute appendicitis was 8 (min-max: 3-10) and the median Alvarado score for negative appendectomy patients was 6.5 (min-max: 2-10). The median Alvarado score of 8 (min-max: 3-10) was significantly more frequently observed in patients histopathologically diagnosed as having acute appendicitis than in those with negative appendectomy $(p=0.00 \mathrm{I})$. The median Karaman score for acute appendicitis was 10.5 (min-max: -3-12), whereas the median Karaman score for negative appendectomy was 3 (min-max: $-3-12)$. The median Karaman score of 10.5 (min-max: -3-12) was significantly more frequent in patients with acute appendicitis than in those with a negative appendectomy $(p=0.00 \mathrm{I})$, (Table 3$)$.

Receiver operating characteristic (ROC) analysis of the Karaman score revealed that the area under the curve (AUC) was significant in distinguishing acute appendicitis from negative appendectomy (AUC: 0.82I, 95\% Cl: 0.732-0.910; $\mathrm{p}<0.00 \mathrm{I}$ ), (Fig. Ia). The cutoff threshold of the Karaman score in distinguishing acute appendicitis from negative exploration was $\geq 9$, with $84.3 \%$ sensitivity, $64.7 \%$ specificity, $92.1 \%$ PPV, and 45.8\% NPV. ROC analysis of the Alvarado score revealed that the AUC was significant in distinguishing acute appendicitis from negative appendectomy (AUC: 0.782, $95 \% \mathrm{Cl}$ : 0.690-0.874; $p=0.001$ ), (Fig. Ib). The cutoff threshold of the Alvarado score in distinguishing acute appendicitis from negative appendectomy was $\geq 8$ with $72.9 \%$ sensitivity, $70.6 \%$ specificity, 92.4\% PPV, and 34.8\% NPV (Table 4). 

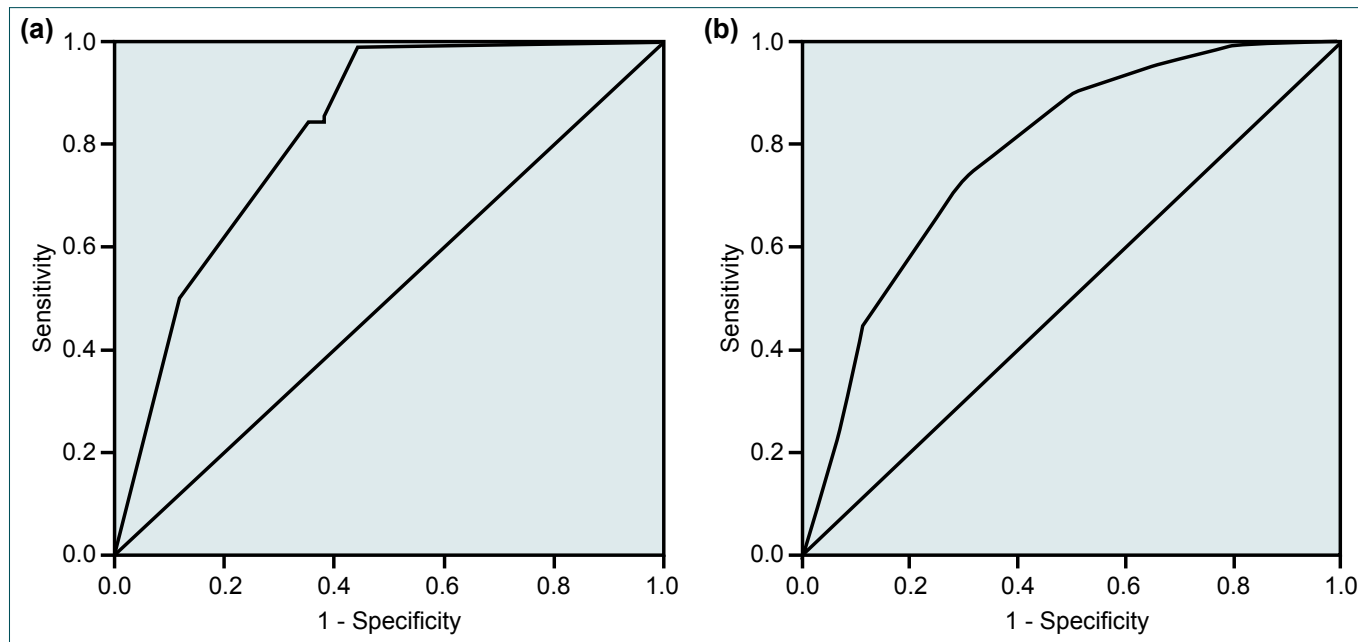

Figure 1. Receiver operating characteristics curve demonstrating the predictive values of the (a) Karaman and (b) Alvarado scoring systems.

A positive correlation was found according to the distribution of the Alvarado $(8</ \geq 8)$ and Karaman scores $(<9 / \geq 9)$. According to the histopathological findings, the frequency of a Karaman score of $\geq 9$ was in 152 of 200 cases (76\%), in 140 of 166 acute appendicitis specimens (84.3\%), and in 12 of 34 non-appendicitis specimens (35\%). On the other hand, the frequency of an Alvarado score of $\geq 8$ was present in $|3|$ of 200 cases (65.5\%), $12 \mathrm{I}$ of 166 acute appendicitis specimens (72.9\%), and in 10 of 34 non-appendicitis specimens (29.4\%). Overall, the frequency of a Karaman score of $\geq 9$ was significantly higher than an Alvarado score of $\geq 8$ (76\% vs $65 \%$; $\mathrm{p}=0.00 \mathrm{I})$. A comparison of the 2 scoring systems according to negative appendectomy revealed no significant difference $(35.3 \%$ vs $29.4 \% ; p=0.625)$. However, the frequency of a Karaman score of $\geq 9$ was significantly higher in acute appendicitis than an Alvarado score of $\geq 8$ ( $84.3 \%$ vs $72.9 \% ; p=0.00$ I).

Each parameter used in the present study was analyzed according to diagnostic sensitivity, specificity, PPV, NPV, positive and negative likelihood ratio, and accuracy. Right iliac fossa

Table 4. Diagnostic performance of Alvarado and Karaman scores

\begin{tabular}{lcc}
\hline & Alvarado & Karaman \\
\hline The area under the ROC curve & 0.782 & 0.821 \\
$95 \%$ confidence interval & $0.690-0.874$ & $0.732-0.910$ \\
P value & $<0.001$ & $<0.001$ \\
Cutoff point & $\geq 8$ & $\geq 9$ \\
Sensitivity & $72.9 \%$ & $84.3 \%$ \\
Specificity & $70.6 \%$ & $64.7 \%$ \\
Positive predictive value & $92.4 \%$ & $92.1 \%$ \\
Negative predictive value & $34.8 \%$ & $45.8 \%$ \\
\hline ROC: Receiver operating characteristic. & &
\end{tabular}

tenderness had the highest sensitivity (100\%), with $83 \%$ accuracy, followed by peritoneal irritation with heavy coughing (sensitivity: $90 \%$, accuracy: $80.4 \%$ ) and anorexia (sensitivity: 89.8\%, accuracy: $80 \%$ ).Fever (sensitivity: $29.5 \%$, accuracy: $37 \%$ ) and a neutrophil ratio of $>75 \%$ (sensitivity: $62.7 \%$, accuracy: $67 \%$ ) had the lowest sensitivity and accuracy (Table 5).

In multivariate logistic regression analysis, both an Alvarado score of $\geq 8$ (OR: 6.644, 95\% Cl: 2.854-15.466; $\mathrm{p}<0.00 \mathrm{I}$ ) and a Karaman score of $\geq 9$ (OR: 10.374, 95\% Cl: 4.383-24.558; $\mathrm{p}<0.00 \mathrm{I})$ were predictive in distinguishing acute appendicitis from negative appendectomy when a correction was made for age and gender. However, when the 2 scores were compared, the Alvarado score lost its efficacy (OR:I.838, 95\% Cl: $0.517-6.530 ; p=0.347)$, whereas the Karaman scoring system maintained its predictive power (OR: 6.586, 95\% Cl: I.89322.917; $p=0.003$ ), (Table 6).

\section{DISCUSSION}

The Karaman score is a new, practical, cost-effective, and feasible scoring system developed on the basis of clinical symptoms, signs, and laboratory data. In contrast to the Alvarado and other scoring systems, fewer parameters are used. In addition, the validation of the parameters used in the Karaman score is well known from previous studies. Like the Alvarado score, the cutoff for the white blood cell (WBC) count in the Karaman score is $>10.000 / \mathrm{mm}^{3}$, with the aim of improving the diagnosis of acute appendicitis. In a meta-analysis including 14 studies, a WBC of $>10.000 / \mathrm{mm}^{3}$ had a sensitivity and specificity of $83 \%$ and $67 \%$, respectively. ${ }^{[6]}$ Similarly, in the study reported by Bates et al.,, ${ }^{[]]}$a WBC count of $<9000 / \mathrm{mm}^{3}$ reduced the negative appendectomy rate. In the present study, the sensitivity and specificity of a WBC of $>10.000 / \mathrm{mm}^{3}$ was $85.5 \%$ and $55.9 \%$ with an accuracy of $80.5 \%$. A polymorphonuclear leucocyte (PMNL) ratio of $>75 \%$ has also been determined to be a discriminator of acute appendicitis, but had a limited 
Table 5. Diagnostic power of each parameter used in the study

\begin{tabular}{|c|c|c|c|c|c|c|c|}
\hline & $\begin{array}{c}\text { Sensitivity } \\
(\%)\end{array}$ & $\begin{array}{c}\text { Specificity } \\
(\%)\end{array}$ & $\begin{array}{l}\text { PPV } \\
(\%)\end{array}$ & $\begin{array}{l}\text { NPV } \\
(\%)\end{array}$ & $+\mathrm{LR}$ & $-\mathbf{L R}$ & $\begin{array}{c}\text { Accuracy } \\
\text { (\%) }\end{array}$ \\
\hline White blood cell $>10.000 / \mathrm{mm}^{3}$ & 85.5 & 55.9 & 90.4 & 44.2 & 1.94 & 0.26 & 80.5 \\
\hline Polymorphonuclear leucocytes $>\% 70$ & 77.1 & 70.6 & 92.8 & 38.7 & 2.62 & 0.32 & 76.0 \\
\hline Polymorphonuclear leucocytes $>\% 75$ & 62.7 & 88.2 & 96.3 & 32.6 & 5.33 & 0.42 & 67.0 \\
\hline Fever $>37.3^{\circ}$ & 29.5 & 73.5 & 84.5 & 17.6 & 1.12 & 0.96 & 37.0 \\
\hline Anorexia & 89.8 & 32.4 & 86.6 & 39.3 & 1.33 & 0.32 & 80.0 \\
\hline Nausea and vomiting & 75.8 & 24.2 & 83.3 & 16.7 & 1.00 & 1.00 & 67.1 \\
\hline Right quadrant tenderness & 100.0 & 0.0 & 83.0 & - & 1.00 & - & 83.0 \\
\hline Peritoneal irritation with coughing & 90.0 & 29.4 & 86.2 & 40.0 & 1.29 & 0.31 & 80.4 \\
\hline Ultrasound & 66.7 & 58.8 & 83.7 & 35.7 & 1.62 & 0.57 & 64.8 \\
\hline Computerized tomography & 91.0 & 51.8 & 91.0 & 51.9 & 1.89 & 0.17 & 84.8 \\
\hline
\end{tabular}

+LR: Positive likelihood ratio; -LR: Negative likelihood ratio; NPV: Negative predictive value; PPV: Positive predictive value.

Table 6. Multivariate logistic regression analysis for distinguishing acute appendicitis from negative appendectomy

\begin{tabular}{lccc}
\hline & Odds ratio & $95 \%$ Cl & $\mathbf{p}^{\dagger}$ \\
\hline $\begin{array}{l}\text { Model I } \\
\text { Age }\end{array}$ & 1.036 & $0.995-1.077$ & 0.083 \\
Male factor & 2.935 & $1.285-6.704$ & $0.01 \mathrm{I}$ \\
Alvarado $\geq 8$ & 6.644 & $2.854-15.466$ & $<0.00$ I \\
Model II & & & \\
Age & 1.039 & $0.998-1.082$ & 0.063 \\
Male factor & 2.988 & $1.255-7.114$ & 0.013 \\
Karaman $\geq 9$ & 10.374 & $4.383-24.558$ & $<0.001$ \\
Model III & & & \\
Age & 1.037 & $0.996-1.080$ & 0.077 \\
Male factor & 3.054 & $1.278-7.299$ & 0.012 \\
Alvarado $\geq 8$ & 1.838 & $0.517-6.530$ & 0.347 \\
Karaman $\geq 9$ & 6.586 & $1.893-22.917$ & 0.003 \\
\hline
\end{tabular}

†Multivariate logistic regression analysis. $\mathrm{Cl}$ : Confidence interval.

clinical significance, with a sensitivity ranging from $66 \%$ to $87 \%$, and a specificity of $33 \%$ to $84 \% .^{[8,9]}$ The cutoff value for the PMNL percentage in the Karaman score was $>70 \%$ due to the high sensitivity reported by Andersson et al. ${ }^{[10]}$ (sensitivity: $93 \%$ in 502 patients) and Fergusson et al. ${ }^{\left[{ }^{11}\right]}$ (sensitivity: $87 \%$ in 1013 patients). Similarly, the sensitivity of a PMNL percentage of $>70 \%$ in the present study was greater than a PMNL percentage of $>75 \%(77.1 \%$ vs $62.7 \%)$ with an accuracy of $76 \%$.

In contrast to the Alvarado score, fever is not used as a parameter in the Karaman score as a result of the limited diagnostic significance demonstrated in other studies. ${ }^{[2-14]}$ The diagnostic sensitivity and accuracy of the presence of a fever of $37.3{ }^{\circ} \mathrm{C}$ or more in the present study was $29.5 \%$ and $37 \%$, respectively, which supported our hypothesis that fever is not a particularly valuable indicator for the diagnosis of acute appendicitis. Furthermore, the presence of nausea and vomiting is also not used in the Karaman score due to low sensitivity $(75.8 \%)$ and specificity $(24.2 \%)$, which has also previously been demonstrated in other studies (sensitivity: $40-72 \%$ and specificity: $45-69 \%) .{ }^{[15-17]}$

In the present study, the cutoff threshold of the Karaman score in distinguishing acute appendicitis from negative appendectomy was $\geq 9$, with an $84.3 \%$ sensitivity, $64.7 \%$ specificity, a $92.1 \%$ PPV, and a $45.8 \%$ NPV. A higher sensitivity (96.2\%) and sensitivity $(90.5 \%)$ were found in a study performed by Nanjundaiah et al. ${ }^{[18]}$ with a Raja Isteri Pengiran Anak Saleha Appendicitis (RIPASA) score of $>7.5$. The sensitivity and specificity of an Alvarado score of $>7$ was $58.9 \%$ and $85.7 \%$ in that study. Similarly, Chong et al. ${ }^{[19]}$ conducted a study that included 192 patients and determined that a RIPASA score of $>7.5$ and an Alvarado score of $>7$ had a diagnostic sensitivity of $98 \%$ and $68.32 \%$, respectively. However, in contrast to the Karaman score, which uses only 6 parameters, the RIPASA score consists of 18 parameters, including urine analysis, which adds a financial burden. The diagnostic sensitivity of the Karaman score appears to be superior when compared with other scoring systems used in the study reported by Erdem et al. ${ }^{[20]} \mathrm{Al}-$ varado (cutoff: 6.5, sensitivity: $81.8 \%$ ) Eskelinen (cutoff: 63.2, sensitivity: $80.5 \%$ ), RIPASA (cutoff: 10.25 , sensitivity: $83.1 \%$ ), and Ohmann (cutoff: 13.75 , sensitivity: $80.5 \%$ ).

The most crucial element is to determine how a negative appendectomy can be prevented when facilities and equipment are limited. Diagnosis of acute appendicitis based on only I or 2 parameters is not reliable. While I positive parameter may support the possibility of acute appendicitis, a negative parameter raises doubts. Additional laboratory tests and radiological 
images, such as C-reactive protein (CRP), CT, or MRI may help to diagnose acute appendicitis, but increase the cost. One of the advantages of the Karaman scoring system is a greater ability to predict a negative appendectomy compared with the Alvarado score, which becomes very valuable in the absence of devices to perform CT or MRI or laboratory tests to assess calcitonin, CRP level, and other molecular markers.

In the present study, the accuracy of US in detecting acute appendicitis was low (sensitivity: $66.7 \%$, specificity: $58.8 \%$, accuracy: $64.8 \%$ ). It is well established that interpretation of US images is operator-dependent. The night shift staff members performing US at our emergency clinic are often junior assistants, which may have affected these results. On the other hand, the diagnostic value of CT has been reported in the literature to be high, with a sensitivity of $91 \%$ and an accuracy of $84.8 \%{ }^{[21]}$

In the present study, the negative appendectomy rate was higher in female patients than in males $(24.9 \%$ vs $11.9 \%$; of total study patients: $17 \%)$, which is comparable with the literature. ${ }^{[22]}$ Lymphoid hyperplasia was the most common leading cause of a negative appendectomy. Both the Alvarado and the Karaman scores failed to distinguish lymphoid hyperplasia from acute appendicitis. CT and US may help in determining lymphoid hyperplasia and prevent false-positive misdiagnoses of appendicitis. ${ }^{[23]}$ When there is doubt, while US is operatordependent, CT is much more helpful in reducing the negative appendectomy rate.

The present study has some limitations. First, the sample size was small. Secondly, a comparison was only made with the Alvarado score.

\section{Conclusion}

Diagnosis of acute appendicitis is still mainly based on history, and clinical and laboratory data. The Karaman score is a costeffective and practical scoring system consisting of 6 parameters that is easy to perform. The Karaman score appears to be more predictive than the Alvarado score in distinguishing acute appendicitis from negative appendectomy.

Conflict of interest: None declared.

\section{REFERENCES}

1. Addiss DG, Shaffer N, Fowler BS, Tauxe RV. The epidemiology of appendicitis and appendectomy in the United States. Am J Epidemiol 1990;132:910-25. [CrossRef]

2. Lee YJ, Kim B, Ko Y, Cho KE, Hong SS, Kim DH, et al. Low-Dose (2-mSv) CT in Adolescents and Young Adults With Suspected Appendicitis: Advantages of Additional Review of Thin Sections Using Multiplanar Sliding-Slab Averaging Technique. AJR Am J Roentgenol 2015;205:W485-91. [CrossRef]

3. Duke E, Kalb B, Arif-Tiwari H, Daye ZJ, Gilbertson-Dahdal D, Keim SM, et al. A Systematic Review and Meta-Analysis of Diagnostic Per- formance of MRI for Evaluation of Acute Appendicitis. AJR Am J Roentgenol 2016;206:508-17. [CrossRef]

4. Al-Abed YA, Alobaid N, Myint F. Diagnostic markers in acute appendicitis. Am J Surg 2015;209:1043-7. [CrossRef]

5. Alvarado A. A practical score for the early diagnosis of acute appendicitis. Ann Emerg Med 1986;15:555-64. [CrossRef]

6. Andersson RE. Meta-analysis of the clinical and laboratory diagnosis of appendicitis. Br J Surg 2004;91:28-37. [CrossRef]

7. Bates MF, Khander A, Steigman SA, Tracy TF Jr, Luks FI. Use of white blood cell count and negative appendectomy rate. Pediatrics 2014;133:e39-44. [CrossRef]

8. Shogilev DJ, Duus N, Odom SR, Shapiro NI. Diagnosing appendicitis: evidence-based review of the diagnostic approach in 2014. West J Emerg Med 2014;15:859-71. [CrossRef]

9. Yang HR, Wang YC, Chung PK, Chen WK, Jeng LB, Chen RJ. Laboratory tests in patients with acute appendicitis. ANZ J Surg 2006;76:71-4.

10. Andersson RE, Hugander AP, Ghazi SH, Ravn H, Offenbartl SK, Nyström PO, et al. Diagnostic value of disease history, clinical presentation, and inflammatory parameters of appendicitis. World J Surg 1999;23:133-40. [CrossRef]

11. Fergusson JA, Hitos K, Simpson E. Utility of white cell count and ultrasound in the diagnosis of acute appendicitis. ANZ J Surg 2002;72:7815. [CrossRef]

12. Cardall T, Glasser J, Guss DA. Clinical value of the total white blood cell count and temperature in the evaluation of patients with suspected appendicitis. Acad Emerg Med 2004;11:1021-7. [CrossRef]

13. Petroianu A. Diagnosis of acute appendicitis. Int J Surg 2012;10:115-9.

14. Andersson RE, Hugander A, Ravn H, Offenbartl K, Ghazi SH, Nyström $\mathrm{PO}$, et al. Repeated clinical and laboratory examinations in patients with an equivocal diagnosis of appendicitis. World J Surg 2000;24:479-85.

15. Ebell MH. Diagnosis of appendicitis: part 1 . History and physical examination. Am Fam Physician 2008;77:828-30.

16. Howell JM, Eddy OL, Lukens TW, Thiessen ME, Weingart SD, Decker WW; American College of Emergency Physicians. Clinical policy: Critical issues in the evaluation and management of emergency department patients with suspected appendicitis. Ann Emerg Med 2010;55:71-116.

17. Laurell H, Hansson LE, Gunnarsson U. Manifestations of acute appendicitis: a prospective study on acute abdominal pain. Dig Surg 2013;30:198-206. [CrossRef]

18. N N, Mohammed A, Shanbhag V, Ashfaque K, S A P. A Comparative Study of RIPASA Score and ALVARADO Score in the Diagnosis of Acute Appendicitis. J Clin Diagn Res 2014;8:NC03-5.

19. Chong CF, Thien A, Mackie AJ, Tin AS, Tripathi S, Ahmad MA, et al. Comparison of RIPASA and Alvarado scores for the diagnosis of acute appendicitis. Singapore Med J 2011;52:340-5.

20. Erdem H, Çetinkünar S, Daş K, Reyhan E, Değer C, Aziret M, et al. Alvarado, Eskelinen, Ohhmann and Raja Isteri Pengiran Anak Saleha Appendicitis scores for diagnosis of acute appendicitis. World J Gastroenterol 2013;19:9057-62. [CrossRef]

21. Karabulut N, Kiroglu Y, Herek D, Kocak TB, Erdur B. Feasibility of lowdose unenhanced multi-detector CT in patients with suspected acute appendicitis: comparison with sonography. Clin Imaging 2014;380:296301. [CrossRef]

22. Chandrasegaram MD, Rothwell LA, An EI, Miller RJ. Pathologies of the appendix: a 10-year review of 4670 appendicectomy specimens. ANZ J Surg 2012;82:844-7.

23. Xu Y, Jeffrey RB, DiMaio MA, Olcott EW. Lymphoid Hyperplasia of the Appendix: A Potential Pitfall in the Sonographic Diagnosis of Appendicitis. AJR Am J Roentgenol 2016;206:189-94. [CrossRef] 
ORİİNAL ÇALIŞMA - ÖZET

\section{Karaman skoru: Akut apandisit tanısında yeni bir skorlama sistemi \\ Dr. Kerem Karaman, ${ }^{1}$ Dr. Metin Ercan, ${ }^{1}$ Dr. Hakan Demir, ${ }^{1}$ Dr. Ömer Yalkın, ${ }^{1}$ Dr. Yener Uzunoğlu, Dr. Kemal Gündoğdu, ${ }^{1}$ Dr. İsmail Zengin,, ${ }^{1}$ Dr. Yakup Ersel Aksoy, ${ }^{2}$ Dr. Erdal Birol Bostancı ${ }^{1}$}

${ }^{1}$ Sakarya Üniversitesi Eğitim ve Araştırma Hastanesi, Genel Cerrahi Kliniği, Sakarya

${ }^{2}$ Sakarya Üniversitesi Eğitim ve Araştırma Hastanesi, Radyoloji Kliniği, Sakarya

AMAÇ: Karaman skorlama sistemi akut apandisit tanısında kullanılan ve 6 parametreden oluşan yeni bir tanısal skorlama sistemidir. Bu çalışmanın amacı Karaman skorunun akut apandisit tanı performansını Alvarado skoru ile karşılaştırmalı olarak ortaya koymaktır.

GEREÇ VE YÖNTEM: Akut apandisit tanısı ile apendektomi yapılan 200 hasta çalışmaya alındı.

BULGULAR: Karaman skorunun akut apandisiti negatif apandektomiden ayırmadaki kestirim değeri $\geq 9$ olup, sensitivitesi \%84.3, spesifitesi \%64.7, pozitif prediktif değeri \%92.I ve negatif prediktif değeri \%45.8 olarak saptandı. Alvarado skorunun akut apandisiti negatif apandektomiden ayırmadaki kestirim değeri ise $\geq 8$ olup, sensitivitesi \%72.9, spesifitesi \%70.6, pozitif prediktif değeri \%92.4 ve negatif prediktif değeri \%34.8 olarak saptandı. Multilojistik regreyon analizinde, yaş ve cinsiyete göre düzeltme yapıldığında; hem Alvarado $\geq 8(\mathrm{OR}=6.644, \% 95 \mathrm{Cl}$ : 2.854-I5.466, p<0.00I) hem de Karaman $\geq 9$ skoru ( $O R=10.374, \% 95 \mathrm{Cl}$ : 4.383-24.558, $\mathrm{p}<0.001$ ) akut apandisiti negatif apandektomiden ayırmada anlamlı olarak etkin saptandı. Ancak, her iki skor bir arada değerlendirildiğinde, Alvarado skoru $\geq 8$ etkinliğini yitirirken $(\mathrm{OR}=1.838, \% 95 \mathrm{Cl}$ : 0.5 I7-6.530 and $\mathrm{p}=0.347)$ Karaman skoru $\geq 9$ prediktif etkinliğini göstermeye devam etmekteydi $(\mathrm{OR}=6.586, \% 95 \mathrm{Cl}$ : I.893-22.917, $\mathrm{p}=0.003)$.

TARTIŞMA: Karaman skoru akut apandisiti negatif apandektomiden ayırt etmede daha etkin saptanmıştır.

Anahtar sözcükler: Akut apandisit; Alvarado skoru; negatif apandektomi; sensitivite; spesifite.

Ulus Travma Acil Cerrahi Derg 2018;24(6):545-55I doi: 10.5505/tjtes.20I8.62436 